\title{
KONSEP PEMBELAJARAN METODE MONTESSORI PADA TINGKAT ANAK USIA DINI DI MASA PANDEMI COVID-19
}

\section{Iga Ayu Anggela, Heni Krisnayanti}

Universitas Pelita Harapan (UPH) Jakarta, Indonesia

Email: anggelakrisna@gmail.com, anggelakrisna2@gmail.com

\begin{abstract}
Abstrak
Pembelajaran menggunakan metode Montessori mulai digemari oleh orang tua di kota-kota besar. Dengan metode Montessori anak diberikan kebebasan memilih materi, media, aktivitas belajar, dan kelompok duduk sesuai dengan keinginan mereka dan peran guru hanya sebagai pengawas. Penelitian ini bertujuan untuk mengetahui konsep pembelajaran metode Montessori pada tingkat anak usia dini di masa pandemi Covid-19 yang mengharuskan pembelajaran dilakukan jarak jauh dari rumah masing-masing siswa. Penelitian ini menggunakan metode study literature, sumber penelitian diambil dari buku, jurnal international, nasional berindeks sinta. Peneliti menyimpulkan bahwa konsep pembelajaran metode montessori untuk anak usia dini dapat dilakukan selama pembelajaran jarak jauh, namun harus dilakukan penyesuaian terhadap beberapa aspek penting, karena terbatasnya ruangan pembelajaran yang nyaman, dan waktu pendampingan anak selama pembelajaran online berlangsung.
\end{abstract}

Kata kunci: Montessori; Anak Usia Dini; Pandemi COVID-19

\begin{abstract}
Learning using the Montessori method is becoming popular with parents in big cities. With the Montessori method, children are given the freedom to choose materials, media, learning activities, and sitting groups according to their wishes and the role of the teacher is only as a supervisor. This study aims to determine the concept of learning the Montessori method at the early childhood level during the Covid-19 pandemic which requires learning to be carried out remotely from each student's home. This research uses a literature study method, the research sources are taken from books, international and national journals with the index of sinta. The researcher concludes that the concept of learning the Montessori method for early childhood can be done during distance learning, but adjustments must be made to several important aspects, due to the limited comfortable learning space, and the time for assisting children online learning.
\end{abstract}

Keywords: Montessori; Early Childhood; COVID-19 Pandemic

Received: 2021-11-22; Accepted: 2021-12-05; Published: 2021-12-20

$\begin{array}{ll}\text { How to cite: } & \text { Anggela,I,A., Krisnayanti,H., (2021) Konsep Pembelajaran Metode Montessori Pada Tingkat Anak } \\ & \text { Usia Dini Di Masa Pandemi Covid-19, Syntax Idea, 3(12), https://doi.org/10.36418/syntax- } \\ & \text { ideav3i11.1542 } \\ \text { E-ISSN: } & 2684-883 X \\ \text { Published by: } & \text { Ridwan Institute }\end{array}$


Iga Ayu Anggela, Heni Krisnayanti

\section{Pendahuluan}

Mengoptimalkan pontesnsi dan mengetahui bakat perkembangan anak diperlukan pendidikan yang dilakukan sejak dini. Menurut Undang-Undang Nomor 20 Tahun 2003 terkait sistem pendidikan nasional menjelaskan pengertian pendidikan anak usia dini yaitu merupakan usaha pendampingan yang dilakukan melalui pemberian pendidikan kepada anak dari umur 0-6 tahun untuk membantu memaksimalkan perkembangan dan siap melangkah ke jenjang pendidikan yang lebih tinggi (Depdiknas, 2003). Perkembangan anak usia dini pada saat mereka masuk taman kanak-kanak, merupakan masa yang penting bagi anak. Peran orang tua dan guru sangat mempengaruhi bagi perkembangan mereka. Pada masa ini seorang anak mulai mengenal lingkungan baru yaitu lingkungan sekolah formal. Dimana anak mulai bersosialisasi dengan teman, guru, lingkungan baru dan hal baru. Berinteraksi dengan dunia baru dan hal baru diluar rumah, akan merangsang perkembangan otak dan kecerdasan seorang anak. Orang tua tidak bisa memaksakan kehendak untuk memuaskan kehendak diri sendiri karena akan berdampak tidak baik dikemudian hari untuk anak, dalam hal ini anak harus diberikan kebebasan dalam pemilihan perkembangannya. Peran orang tua disini sebagai pengamat dan pendamping kebutuhan anak masing-masing (Mayar, 2013).

Pemilihan suatu metode pembelajaran untuk anak dapat berlangsung sedari dini, pemilihan metode akan mempengaruhi bagaimana efektivitas dan kreativitas seorang anak terutama mereka yang baru memasuki Taman Kanak-Kanak. Banyak metode yang digunakan dalam pembelajaran yang dapat mendukung perkembangan kecerdasan anak, salah satu yang sedang digemari orang tua di kota-kota besar saat ini adalah metode pembelajaran Montessori, untuk meningkatkan rasa kemandirian, tanggung jawab, komunikasi anak (Wahyuningsih, 2019). Menurut (Hainstock, 2008) menjelaskan dalam bukunya Maria Montessori berpendapat bahwa pendidikan pada anak tidak perlu dipaksakan, berikan anak ruang kebebasan untuk memilih apa yang mereka inginkan ketika belajar untuk memaksimalkan perkembangan otaknya. Menggunakan pembelajaran dengan metode Montessori seorang anak akan diberikan pilihan sendiri atau kebebasan dalam membuat keputusan baik itu belajar, bermain, berkomunikasi, berkreasi sesuai dengan kebutuhan mereka sendiri. Metode montessori menekankan pada pembelajaran berfokus pada siswa dan peran guru dalam pembelajaran Montessori ini sebagai pendamping ketika anak mengalami kesulitan atau ada hal-hal yang tidak diinginkan terjadi.

Pada akhir tahun 2019 ditemukan virus baru yang menyerang pernapasan manusia dan menyebabkan kematian di kota Wuhan, China, WHO telah menetapkan Covid-19 sebagai virus yang dapat menyebar dari udara dan menyatakan dunia mengalami pandemi Covid-19 (WHO team, 2020). Virus Covid-19 tersebut sangat cepat menyebar sampai Indonesia, dan untuk memutus rantai penyebaran virus Covid-19 pemerintah mengeluarkan peraturan pemerintah darurat mengharuskan seluruh aktivitas dilakukan dari rumah seperti bekerja, belanja, olahraga, termasuk sekolah yang dilakukan secara daring atau online di rumah masing-masing untuk memutus rantai penyebaran virus Covid-19 di lingkungan sekolah. Seluruh sekolah mengharuskan melakukan 
penyesuaian dari pembelajaran tatap muka menuju PJJ (pembelajaran jarak jauh). Dengan pembelajaran online menjadikan suatu tantangan tersendiri baik itu sekolah, guru, maupun orang tua terhadap proses pembelajaran anak dirumah. Sekolah yang menggunakan metode montessori sebagai model pembelajaran juga harus melakukan penyesuaian supaya peserta didik dapat terus menggunakan metode montessori walaupun pembelajaran dilakukan dari rumah masing-masing (Wahyuningsih, 2019).

Pada jurnal ini akan membahas lebih dalam terkait implementasi konsep metode Montessori pada pendidikan anak usia dini di masa pandemi Covid-19. Tujuan dari artikel ini untuk mengetahui bagaimana konsep pembelajaran metode Montessori di Tingkat anak usia dini pada masa pandemi covid-19 berjalan. memberikan referensi bacaan untuk guru, siswa, dan orang tua,

\section{Metode Penelitian}

Pada artikel ini, menggunakan metode studi literatur terkait konsep pembelajaran metode Montessori di tingkat anak usia dini. Literatur yang dicari disesuaikan dengan judul yang telah dipilih oleh peneliti. Berbagai litelatur dicari diberbagai sumber seperti buku, jurnal ilmiah, artikel ilmiah, dan website resmi yang menerbitkan jurnal terindeks sinta. Studi literatur ini akan memberikan kesimpulan dari apa yang akan peneliti bahas selama penelitian berlangsung.

\section{Hasil dan Pembahasan}

\section{a. Biography Maria Montessori}

Maria Montessori seorang wanita yang mempunyai pengaruh luar biasa di bidang Pendidikan dan telah diakui oleh dunia. Montessori mendedikasikan hidupnya untuk mengembangkan motode Pendidikan yang berbeda dari metode konvensioanl yang digunakan saat itu. Montessori juga sebagai pintu pembuka bahwa wanita juga dapat mendapatkan Pendidikan yang layak seperti laki-laki.

Maria Montessori lahir di Italia, pada tanggal 31 Agustus 1870 kota Chiaravalle. Lahir dari keluarga yang terpandang dan anak prempuan satu-satunya di keluarga membuat Montessori mendapatkan pendidikan tinggi sama seperti kaum laki-laki. Sebelum memasuki sekolah menegah Teknik, Maria telah merasakan pendidikan dasar di kota roma italia dimana pendidikan yang didapatkan oleh maria masih mengikuti system pembelajaran tradisional dimana guru menjadi sumber informasi siswa, menggunakan satu buku yang didalamnya memiliki beberapa mata pelajaran yang dijadikan satu dalam buku. Siswa juga masih menggunakan metode penghapalan dan kemudian akan didikte ketika ujian tiba. Maria merupakan satusatunya wanita yang masuk dan lulus dalam sekolah Teknik Regia Scoula Technica Michelangelo Buonarroti pada tahun 1886 dengan nilai tinggi dan kemudian melanjutkan studinya di sekolah Kedokteran Universitas Roma tahun 1890, dan lagilagi Montessori menjadi wanita pertama yang bisa masuk sekolah kedokteran walaupun sebelumnya beliau sempat ditolak karena yang bisa masuk hanya kaum laki-laki. 
Setelah lulus dari sekolah kedokteran Maria melanjutkan magangnya di klinik psikiatri Universitas Roma, Maria juga mendapatkan kesempatan menjadi asisten dokter pada saat menjalani magang. Selama magang berlangsung Maria Montessori melihat berbagai stase yang ada di klinik, dan beliau tertarik ketika mengunjungi stase anak-anak yang memiliki kebutuhan khusus, Montessori melihat anak-anak berkebutuhan khusus dijadikan satu rungan dengan orang dewasa, anak-anak tersebut tidak mendapatkan pendidikan dan hanya ada pendampingan dari perawat. Bagaimana pendampingan perawat mengajarkan anak-anak tersebut membuat Montessori tertarik dengan pendidikan khusus untuk anak-anak berkebutuhan yang tidak bisa mengikuti pembelajaran seperti anak-anak normal lainnya. Sehingga Maria Montessori mencentuskan metode pembelajaran untuk anak berkebutuhan khusus (Montessori, 2004).

\section{b. Sejarah Metode Montessori}

Sejarah perkembangan metode Montessori terkait keterbelakangan mental dan gangguan psikologis pada anak, didukung oleh karya dari Jean-Marc Gaspard Itard (1774-1838) dan karya Edouard Seguin (1812-1880). Untuk memberikan ruang khusus bagi anak-anak berkebutuhan khusus pada tahun 1900, Montessori dan Dr Giuseppe Montesano mendirikan sebuah sekolah yang bernama Scoula Magistrale Ortofrenica yang diperuntukan untuk anak-anak tunarungu dan tunagrahita, Montessori dipercaya sebagai kepala sekolah pada saat itu. Selama berlangsungnya pembelajaran di sekolah khusus, dan melihat dari karya Itard dan Seguin, Montessori menyimpulkan metode yang sekarang dia terapkan pada anak berkebutuhan khusus juga dapat diterapkan pada anak normal terutama mereka yang masih muda.

Tahun 1970 montessori mendapatkan kesempatan yang sangat berharga dari direktur jendral Instituto Romano yang bernama Edoardo Talamo meminta Montessori mendirikan sebuah sekolah untuk anak- anak di daerah kumuh di kota Roma tepatnya di distrik San Lorenzo. Talamo memberikan tantangan kepada Montessori untuk membangun sebuah sekolah di rumah petak kecil, karena talamo sering melihat orang tua yang meninggalkan anak di bawah umur dirumah mereka tanpa pengawasan karena mereka bekerja. Montessori melihat kesempatan ini sebagai jalan untuknya menjadikan sekolah tersebut sebagai tempat penelitian atau labolatorium untuk metode yang sedang dia kembangkan. Sekolah pertama yang Montessori bangun bernama Casa dei Bambini atau rumah anak. Pada pembukaan sekolah pertama Montessori telah menerima kurang lebih 50 anak dari berbagai usia 3-7 tahun.

Sekolah Montessori dibangun untuk menumbuhkaan kepekaan sensorik anak, ketangkasan, menumbuhkan kemandirian dan kepercayaan diri dalam melakukan kegiatan.

Cas a dei Bambini menggunakan kurikulum didasari dari prinsip Montessori yaitu periode "sensitife anak", karena pada fase ini anak mengalami masa penting dalam perkembangan mereka atau masa emas. Dengan kurikulum tersebut 
Montessori membebaskan anak-anak memiliki materi, alat pembelajaran, memotivasi diri mereka sendiri, mengoreksi diri sendiri.

Berdasarkan periode sensitive, melalui observasi dan eskperimen, montessori merancang kurikulum untuk memenuhi kompetensi dalam 5 bidang:

1. Keterampilan hidup praktis merupakan pelatihan kegiatan sederhana sehari-hari anak untuk meningkatkan kemandirian dan mengurangi ketergantungan terhadap orang dewasa contoh kegiatan hidup praktis adalah mencuci alat makan, mencuci tangan, membersihkan kelas, memakai baju sekolah, mengikat rambut, mengembalikan media pembelajaran yang telah dipakai ketempatnya, dsb (Fitri, .2018).

2. Pelatihan motoric dan sensorik,: merupakan pelatihan yang bertujuan untuk mengenalkan anak-anak perbedaan warna, bentuk benda, bentuk nada dan suara yang ada disekitar merekacontoh pembelajaran yang dapat dilakukan sekolah menyediakan berbagai jenis bentuk bangun ruang 3 dimensi dengan warna yang berbeda, menyusun menara kayu dari 10 jenis persegi empat yang berbeda bentuk sehingga diharapkan anak dapat mengenali, mengelompokkan, dan membandingkan objek dengan baik (Rakimahwati, 2013).

3. Keterampilan bahasa dan matematika: diaman anak-anak diajarkan membaca, menulis, dan berhitung dari media yang dibuat oleh guru seperti membuat kartu huruf A-Z kemudian anak-anak akan menghafal satu persatu huruf sampai mengerti kata dan menyusunnya dengan baik semua menggunakan media pembelajaran (Asiah, 2018).

4. Keterampilan fisik,social, dan budaya: keterampilan yang didapatkan anak di lingkungan sekitarnya, baik itu ketika mereka bekerjasama dan bertanggung jawab atas benda, tumbuhan, hewan, dan belajar menciptakan rasa hormat kepada diri sendiri dan orang lain (Putri, 2019).

5. Pembentukan nilai dan Pendidikan karakter: merupakan pembentukan yang telah dilakukan oleh anak dari mereka lahir kedua sampai 18 tahun dari pandangan montessori, selama proses pembentukan nilai dan karakter orang tua memiliki peranan penting didalamnya (Montessori, 2004).

\section{c. Tahap-tahap Perkembangan Metode Montessori}

Metode montessori memiliki prinsip bahwa perkembangan pendidikan anak terjadi sesuai dengan kebutuhan anak sendiri, tidak bisa disamakan dengan teman satu kelasnya. Montessori juga meyakini bahwa dengan membebaskan anak memilih apa yang ingin anak pelajari akan mempercepat proses penerimaan materinya. Tahap-tahap perkembangan anak dalam metode montessori dibagi menjadi 3 tahap besar:

1. Usia 0-6 tahun (Absorbent mind): di fase ini seorang anak akan melalui proses berkomunikasi, pengenalan lingkungan, penyerapan informasi dapat dilakukan dengan lebih cepat oleh anak. Dengan penyerapan pikiran yang dimiliki anak di fase ini, proses belajar menggunakan bahasa, dan matematika akan diterima 
secara bertahap menggunakan media yang telah dikembangkan oleh guru, disesuaikan untuk masing-masing anak.

2. Usia 6-12 tahun: pada fase ini anak mengembangkan, memperkuat, memperluas dan mengasah kemampuan yang telah mereka pelajari di fase pertama, anak telah memasuki sekolah formal dan belajar berbagai mata pelajaran.

3. Usia 12-18 tahun: pada fase ini anak telah memasuki masa remaja, memasuki perubahan fisik dan emosi untuk mempersiapkan anak masuk ke fase kedewasaan (Montessori, 2004).

Dari ketiga tahap diatas tahap terpenting dalam perkembangan montessori adalah tahap pertama, tahap perkembangan keemasan anak.

\section{d. Perkembangan dan Pendidikan Anak Usia Dini}

Anak usia dini merupakan anak yang memiliki rentan usia 0-6 tahun, memiliki masa perkembangan yang penting untuk tahap perkembangan berikutnya. Untuk memaksimalkan perkembangan kognitif anak, perkembangan motoric, bahasa, sosial anak diperlukan pendidikan anak usia dini. Pendidikan anak usia dini berlangsung sampai sebelum anak memasuki sekolah dasar. Tujuan dari diberikan pendidikan anak usia dini adalah untuk mempersiapkan anak sebelum memasuki tingkat dasar, materi dan metode pembelajaran yang diberikan juga disesuikan dengan kebutuhan masing-masing anak serta kebijakan dari orang tua (Qudsyi, 2010)

Proses perkembangan dan pertumbuhan anak usia dini memiliki sifat yang unik dibandingkan dengan fase yang lain sehingga memilik karakteristik yang khas. Keunikan dalam perkembangan anak dibagi dalam 3 rentan usia: Perkembangan anak usia dini (Idris, 2016):

1. Usia 0-1 tahun masuk fase bayi, pada fase ini anak mengalami perkembangan yang cukup cepat. Pada usia ini anak akan banyak belajar keterampilan baru dalam hidupnya. Seperti mempelajari keterampilan motoric anak belajar cara bergerak dan berpindah ke tempat lain, sensorik dan panca indera anak mulai belajar mengambil barang, membedakan tekstur benda, mendengar,mengecap rasa, melihat lingkungan, komunikasi pada fase ini anak sudah bisa berkomunikasi dasar dengan bahasa bayi kepada orang tua mereka seperti ketika anak lapar maka komunikasi yang diberikan adalah menangis.

2. Usia 2-3 tahun masuk fase balita: merupakan fase mematangkan kemampuan dan keterampilan yang mereka dapatkan pada fase yang pertama, pada fase ini anak sudah bisa berjalan dan berlari, lebih baik ketika berkomunikasi anak sudah mampu memahami komunikasi orang tua dan sudah bisa menyebutkan kaliman dasar, dan sangat aktif belajar hal-hal baru yang mereka temui di luar rumah.

3. Usia 4-6 tahun masuk fase pra-sekolah: dalam fase ini anak aktif melakukan berbagai activitas melatih otot-otot, perkembangan bahasa anak semakin meningkat dapat memahami maksud orang lain, dapat mengekspresikan pikiran mereka, kemampuan berpikir anak sangat cepat. 
Perkembangan karakteristik anak usia dini diantaranya:

1. Perkembangan Fisik Motorik: pada perkembangan fisik, tidak selalu sama untuk semua anak. Beberapa anak ada yang pertumbuhannya cepat, yang lain tumbuh lambat. Pertumbuhan sisik motorik anak terjadi sangat cepat pada saat anak menginjak umur 3 tahun, karena pada umur ini anak sedang aktif bermain, berlari, dan rasa ingin tahu terhadap hal baru sangat tinggi dimulai dari mereka buka mata hingga tutup mata. Perkembangan ini sangat mempengaruhi perkembangan otot, motoric, dan bermain anak.

2. Perkembangan Kognitif: pada perkembangan kognitif anak usia dini dari buku (Slavin, 2011) dibagi menjadi 3, pertama penerimaan infomasi baru dan digabungkan dengan informasi yang telah dimiliki anak atau bisa disebut Asimilasi, kedua perpaduan dalam proses penyatuan informasi baru dan informasi anak bertujuan memperluas pengetahuan anak atau Akomodasi, ketiga Ekuilibrium mengatasi suatu masalah dengan menggunakan mengkombinasikan informasi yang baru diterima dengan informasi lama yang telah anak miliki terhadap solusi untuk mengatasi masalah atau konflik.

3. Perkembangan Sosio Emosional: pada fase ini anak memiliki perkembangan sosial sesuai dengan tingkatan umurnya, saat anak menginjak umur 0-1tahun perkembangan sosialnya cenderung pada lingkungan keluarga inti, anak mulai bersosialisasi dengan orang-orang terdekat yang sering dia temui setiap harinya, naik ke umur 2-3 tahun perkembangan sosial anak mulai berkembang lebih luas bertemu dengan teman-teman sebayanya, naik ke 4-6 tahun perkembangan social anak lebih luas lagi sudah masuk dalam sekolah formal sehingga sudah mampu mencari sahabat melalui seleksi selama aktivitas bersama yang dilakukan di sekolah.

4. Perkembangan emosional anak memiliki 3 fase yaitu pertama usia 0-1 tahun emosi yang muncu dari diri anak adalah emosi yang masih bisa diatur dengan baik, anak bermain dengan tenang, istirahat dengan teratur, dapat beradaptasi dengan baik di lingkungan sekitarnya memiliki rasa empati dan kasih sayang yang tinggi, kedua usia 2-3 tahun emosi yang dimunculkan sudah mulai meningkat dengan menangis, sulit diatur atau diminta tidur siang, suka bermain terus terusan, ketiga usia 4-6 tahun emosi yang dimiliki anak pada usia ini masih membawa emosi sebelumnya dan semakin meningkat seperti anak mulai tantrum ketika keinginannya tidak dipenuhi, anak mulai tidak aktif dalam suatu kegiatan, krang percaya diri, cemas, iri hati, gembira (Purnamasari, 2006).

5. Perkembangan Bahasa: sama seperti perkembangan sosio emosional anak, perkembangan bahasa juga memiliki tingkatan umur pertama umur 0-1 tahun dimulai dari bahasa mengoceh secara abstrak sampai mampu mengoceh untuk belajar bahasa dasar, ditingkat usia 2-3 tahun perkembangan bahasa anak telah memasuki mampu mengucapkan 1sampai 3 kata dan melatih membuat kalimat-kalimat sederhana, ketiga umur 4-6 tahun anak sudah mulai sempurna dalam mengucapkan kalimat, sudah mampu berkomunikasi dan mengeluarkan keinginan mereka lewat komunikasi (Rahman, 2009). 
Implementasi Metode Montessori pada Pendidikan Anak Usia Dini di masa pandemi Covid-19

Implementasi yang akan peneliti jelaskan bagaimana metode montessori ini diterapkan dimasa pandemi Covid-19, dimana pembelajaran dilakukan secara daring atau jarak jauh dari rumah siswa masing-masing. Berdasarkan hasil penelitian (Permataputri \& Syamsudin, 2021), ditemukan bahwa kurikulum yang digunakan di sekolah menggunakan kurikulum 2013 PAUD dengan metode Montessori di SAFA Islamic Preschool. Perubahan-perubah atau penyesuaian yang dilakukan sekolah saat pembelajaran jarak jauh oleh tim kurikulum adalah penyederhanaan materi pembelajaran disesuaikan dengan sekolah, pendanaan, dan keadaan orang tua siswa. Jika saat pembelajaran tatap muka anak dapat melakukan kegiatan empat sampai lima kali dalam sehari, ketika pembelajaran daring seperti saat ini kegiatan tersebut disederhanakan lagi hanya sepuluh kali dalam seminggu, atau maksimal dua kegiatan pembelajaran setiap harinya, walaupun hanya dua kali kegiatan pembelajaran namun guru memaksimalkan pembelajaran tetap menerapkan 5 perkembangan anak yang digagas oleh model pembelajaran Montessori. Selain penyederhanaan materi, sekolah juga mempertimbangkan materi dan media yang digunakan oleh siswa dan orang tua saat pembelajaran dirumah. Untuk media guru mempersiapkan media selama satu minggu dan akan diserahkan secara rutin kepada orang tua siswa di hari minggu. Orang tua juga ikut serta dalam evaluasi anak-anaknya selama pembelajaran jarak-jauh berlangsung untuk mengetahui sejauh mana perkembangan yang telah dicapai setiap anak.

\section{Kesimpulan}

Dapat kita simpulkan metode montessori menekankan pada perkembangan yang baik pada anak terjadi ketika anak memasuki umur 0-6 tahun (Absorbent mind), sering disebut masa penyerapan pikiran pada masa ini seorang anak akan aktif dalam penyerapan informasi, materi, bahasa, dan matematika. Masuk sebagai masa golden age dan masa sensitif anak membuat masa penyerapan pikiran sangat perlu diperhatikan untuk mendapatkan hasil perkembangan kompetensi yang maksimal untuk anak dengan tujuan anak lebih siap masuk ke fase sekolah dasar. Metode montessori memiliki keterkaitan yang erat dengan perkembangan pendidikan anak usia dini, fase yang penting dalam PAUD adalah ketika mereka memasuki usia 4-6 tahun, pada usia tersebut anak memasuki masa paling aktif dalam perkembangan motoric, sensorik, bahasa, dan sosio emosional. Implementasi metode montessori pada pendidikan anak usia dini selama pandemi Covid-19, dapat berjalan sebagaimana mestinya sama seperti sebelum pandemi, namun ada beberapa aspek yang diperlukan penyesuaian yang perlu diperhatikan selama pembelajaran jarak jauh berlangsung, yaitu penyederhanaan materi, durasi kegiatan pembelajaran, media yang disesuaikan dengan sekolah, siswa, orang tua, dan cara mengevaluasi siswa yang dibantu langsung oleh orang tua. 


\section{BIBLIOGRAFI}

Asiah, Nur. (2018). Pembelajaran calistung Pendidikan anak usia dini dan ujian masuk calistung sekolah dasar di Bandar Lampung. Terampil: Jurnal Pendidikan Dan Pembelajaran Dasar, 5(1), 19-42.Google Scholar

Depdiknas. (2003). Undang-undang RI No.20 tahun 2003.tentang sistem pendidikan nasional.

Fitri, Izza. (2018). Peningkatan Kemandirian Anak Melalui Pembelajaran Practical Life Di Tk Annisa. Raudhatul Athfal: Jurnal Pendidikan Islam Anak Usia Dini, 2(1), 23-45. Google Scholar

Hainstock, Elizabeth G. (2008). kenapa Montessori. Keunggulan Metode Montessori Tumbuh Kembang Anak. Jakarta: Mitra Media. Google Scholar

Idris, Meity H. (2016). Karakteristik Anak Usia Dini. Permata: Jurnal Pendidikan Anak Usia Dini, 37-43. Google Scholar

Mayar, Farida. (2013). Perkembangan sosial anak usia dini sebagai bibit untuk masa depan bangsa. Al-Ta Lim Journal, 20(3), 459-464. Google Scholar

Montessori, Maria. (2004). The Montessori method: the origins of an educational innovation: including an abridged and annotated edition of Maria Montessori's The Montessori method. Rowman \& Littlefield. Google Scholar

Permataputri, Dhiah Intan, \& Syamsudin, Amir. (2021). Pembelajaran Nilai Agama dan Moral Anak Usia Dini melalui Metode Montessori selama Pandemi Covid-19. Jurnal Obsesi: Jurnal Pendidikan Anak Usia Dini, 6(2), 693-703. Google Scholar

Purnamasari, Ariavita. (2006). Kamus Perkembangan Bayi dan Balita. Penerbit Erlangga. Google Scholar

Putri, Suci Utami. (2019). Pembelajaran sains untuk anak usia dini. UPI Sumedang Press. Google Scholar

Qudsyi, Hazhira. (2010). Optimalisasi Pendidikan Anak Usia Dini Melalui Pembelajaran yang Berbasis Perkembangan Otak. Buletin Psikologi, 18(2). Google Scholar

Rahman, Ulfiani. (2009). Karakteristik perkembangan anak usia dini. Lentera Pendidikan: Jurnal Ilmu Tarbiyah Dan Keguruan, 12(1), 46-57. Google Scholar

Rakimahwati, Rakimahwati. (2013). Perencanaan Program Pembelajaran Pada Anak Usla Dini. Google Scholar

Slavin, Robert E. (2011). Instruction based on cooperative learning. Handbook of Research on Learning and Instruction, 358-374. Google Scholar 
Iga Ayu Anggela, Heni Krisnayanti

Wahyuningsih, Ana Setesia Dwi. (2019). Efektivitas Cerita Binatang Berbahasa Jawa Untuk Meningkatkan Kemampuan Kosakata Bahasa Jawa Anak (Penelitian di Taman Kanak-Kanak Tunas Mulya Desa Karangmulyo, Kecamatan Purwodadi Kabupaten Purworejo). Skripsi, Universitas Muhammadiyah Magelang. Google Scholar

WHO team. (2020). WHO-convened Global Study of the Origins of SARS-CoV-2. World Health Organization, $9 . \quad$ Retrieved from https://www.who.int/publications/m/item/who-convened-global-study-of-theorigins-of-sars-cov-2. Google Scholar

\section{Copyright holder:}

Iga Ayu Anggela, Heni Krisnayanti (2021)

\section{First publication right:}

Syntax Idea

This article is licensed under:

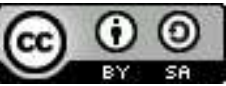

